\title{
Serine/Threonine-Protein Kinase A-Raf
}

National Cancer Institute

\section{Source}

National Cancer Institute. Serine/Threonine-Protein Kinase A-Raf. NCI Thesaurus. Code C18535.

Serine/threonine-protein kinase A-Raf (606 aa, $\sim 68 \mathrm{kDa}$ ) is encoded by the human ARAF gene. This protein plays a role in protein phosphorylation, signal transduction and the negative regulation of apoptosis. 